\title{
Oxfendazole Resistance in Gastrointestinal Nematodes of Beetal Goats at Livestock Farms of Punjab (Pakistan)
}

\author{
M. SAEED, Z. IQBAL, A. JABBAR \\ Chemotherapy Laboratory, Department of Veterinary Parasitology, University of Agriculture,
} Faisalabad, Pakistan

Received June 29, 2006

Accepted November 6, 2006

\begin{abstract}
Saeed M., Z. Iqbal, A. Jabbar: Oxfendazole Resistance in Gastrointestinal Nematodes of Beetal Goats at Livestock Farms of Punjab (Pakistan). Acta Vet Brno 2007, 76: 79-85.

This study was carried out to screen goat farms for anthelmintic resistance (AR) against oxfendazole (OXF) and to determine contributory factors for its development.

For this purpose, Beetal goat farms $(n=18)$ were randomly selected, with natural mixed gastrointestinal nematodosis infection. In vivo (faecal egg count reduction test) and in vitro (egg hatch assay) tests were used to ascertain the presence of AR while a scorecard was used to determine the role of possible contributory factors for oxfendazole resistance. For in vivo test, the experimental animals were divided into two groups of 10 animals each; one group received OXF treatment, while the other served as control. Pre- and post-treatment coproculture was performed to identify the species and genera of nematodes. Egg hatch assay (EHA) was used to confirm the results of FECRT.

Fecal egg count reduction test (FECRT) revealed the development of resistance on six farms and post-treatment larval cultures indicated Haemonchus contortus, Trichostrongylus colubriformis, Cooperia curticei, Teladorsagia circumcincta and Oesophagostomum spp. as dominant species with resistance. Furthermore, EHA confirmed the results of FECRT. Among the presumptive factors for AR, the highest composite score was for rotation of anthelmintics followed by treatment frequency, dose rate and nature of medication.

The scorecard for the development of AR, used in this study, may be helpful for the assessment of contributory factors of AR.
\end{abstract}

Oxfendazole, resistance, Beetal goat, Pakistan, in vivo test

Gastrointestinal nematodes adversely affect animal production causing huge economic losses all over the world (Chandrawathani et al. 1999; Vázquez 2000), and the livestock in Pakistan is no exception to it. Use of chemicals for the treatment and control of gastrointestinal parasites is most widely practiced throughout the world (Ancheta et al. 2004). Development of AR to commercially available drugs has, however, become a serious problem (Mascie-Taylor and Karim 2003; Kaplan 2004; Coles et al. 2006; J abbar et al. 2006). In many parts of the world, therefore, anthelmintics are loosing their efficacy; e.g. in Europe (Requejo-Fernandez et al. 1997), Africa (Mwamachi et al. 1995), Australia (Waller 1986), New Zealand (McKenna et al. 1990), Pakistan (Saddiqi et al. 2006), Texas (Miller and Craig 1996) and Virginia (Zajac and Gipson 2000).

In Pakistan, one of the important factors of high prevalence of nematodes in goats (Iqbal et al. 1986; Azad et al. 1997; Iqbal et al. 2005; Lateef et al. 2005; Raza et al. 2006) may be the treatment failure with the commonly used anthelmintics (Afaq et al. unpublished data). The present study was, therefore, carried out to screen the gastrointestinal nematodes of Beetal goats for the development of resistance against oxfendazole, one of the commonly used anthelmintics. In addition, a scorecard was developed to ascertain the role of some of the contributory factors in the development of AR.

\footnotetext{
Address for correspondence:

Dr. Abdul Jabbar, DVM, MSc (Hons.), Lecturer

Chemotherapy Laboratory

Department of Veterinary Parasitology

University of Agriculture

Faisalabad-38040, Pakistan
}

Phone: +92-41-9201106

Fax: +92-41-9200161-70 Ext. 3130

E mail: jabbaruaf@yahoo.co.uk

http://www.vfu.cz/acta-vet/actavet.htm 


\section{Materials and Methods}

Eighteen Beetal goat farms (Table 1) in the province of Punjab (Pakistan) were screened at random for AR using faecal egg count reduction and egg hatch tests.

Table 1. Flock composition and percentage reduction of faecal egg counts with lower confidence limits of $95 \%$ confidence interval in goats treated with oxfendazole

\begin{tabular}{|c|c|c|c|c|c|}
\hline Flock No. & Age (months) & Sex & $\begin{array}{c}\% \\
\text { Reduction }\end{array}$ & $\begin{array}{c}\text { Confidence } \\
\text { Limits }\end{array}$ & $\begin{array}{c}\text { Resistant/Suspected/ } \\
\text { Susceptible }\end{array}$ \\
\hline $1(\mathrm{n}=40)$ & $6-9$ & Male & 94 & $81-98$ & Resistant \\
\hline $2(\mathrm{n}=48)$ & $6-10$ & Female & 100 & $98-100$ & Susceptible \\
\hline $3(\mathrm{n}=40)$ & $9-12$ & Female & 87 & $25-98$ & Resistant \\
\hline $4(\mathrm{n}=40)$ & $12-15$ & Female & 89 & $55-97$ & Resistant \\
\hline $5(\mathrm{n}=40)$ & $12-18$ & Female & 93 & $85-97$ & Resistant \\
\hline $6(\mathrm{n}=40)$ & $12-24$ & Male & 82 & $42-95$ & Resistant \\
\hline $7(\mathrm{n}=40)$ & $12-24$ & Female & 99 & $92-100$ & Susceptible \\
\hline $8(\mathrm{n}=48)$ & $15-25$ & Female & 98 & $95-99$ & Susceptible \\
\hline $9(\mathrm{n}=40)$ & $15-25$ & Female & 96 & $72-99$ & Suspected \\
\hline $10(\mathrm{n}=40)$ & $15-25$ & Female & 96 & $83-99$ & Suspected \\
\hline $11(\mathrm{n}=48)$ & $15-25$ & Female & 99 & $97-100$ & Susceptible \\
\hline $12(\mathrm{n}=48)$ & $15-25$ & Female & 98 & $92-99$ & Susceptible \\
\hline $13(\mathrm{n}=40)$ & $15-25$ & Female & 95 & $70-99$ & Suspected \\
\hline $14(\mathrm{n}=40)$ & $15-25$ & Female & 97 & $79-99$ & Suspected \\
\hline $15(\mathrm{n}=40)$ & $15-25$ & Female & 98 & $92-100$ & Susceptible \\
\hline $16(\mathrm{n}=40)$ & $15-25$ & Female & 80 & $18-95$ & Resistant \\
\hline $17(\mathrm{n}=40)$ & $15-25$ & Female & 97 & $92-97$ & Susceptible \\
\hline $18(\mathrm{n}=40)$ & $15-25$ & Female & 99 & $87-100$ & Suspected \\
\hline
\end{tabular}

$\mathrm{n}=$ Number of animals

The FECRT was conducted according to the World Association for the Advancement of Veterinary Parasitology (WAAVP) guidelines for detection of anthelmintic resistance (Coles et al. 1992). Briefly, faecal samples (3 - $5 \mathrm{~g}$ ) were collected and examined before medication from each animal directly from the rectum. The eggs per gram of faeces (EPG) were recorded using the McMaster technique (Soulsby 1982). On the basis of EPG, animals were randomly divided into two groups of an equal number of animals each. The treated group was given $2.265 \%$ w/v oxfendazole (Oxazole, Manufactured by Star laboratories, 23-Km, Multan Road, Lahore, Pakistan) as per manufacturer's recommendations while the other served as untreated control. Coproculture was carried out to assess the composition of infection before and after medication. For this purpose, pooled collections $(\sim 5 \mathrm{~g}$ from each animal making a total of $50 \mathrm{~g}$ ) from each experimental group were used for coprocultures on days 0 (pretreatment) and 14 (post-treatment). Larvae were recovered through Baermann apparatus (MAFF 1986) and identification of third stage larvae $\left(\mathrm{L}_{3}\right)$ was done using the key described by MAFF (1986) and van Wyk et al. (2004).

The percentage reduction was calculated by the formula $100(1-\mathrm{Xt} / \mathrm{Xc})$ where " $\mathrm{t}$ " was treated egg count and "c" control group egg count on day 14 post treatment. The nematodes were declared having developed resistance if (i) the percentage reduction in the egg count was less than $95 \%$ and (ii) the lower limit of $95 \%$ confidence level was less than $90 \%$ as described by Coles et al. (1992). If only one of the two criteria was met then resistance was suspected.

Animals with an evidence of resistant nematodes with FECRT were subjected to EHT following the method of Le Jambre (1976) with minor modifications (Coles et al. 1992). Briefly, 15 concentrations of oxfendazole ( 0.001 to $22.65 \mu \mathrm{g} \cdot \mathrm{ml}^{-1}$ ) were prepared by twofold serial dilution using $0.1 \% \mathrm{NaCl}$ (diluent) to enable the calculation of the dose required to prevent $50 \%$ of the viable eggs hatching $\left(\mathrm{LC}_{50}\right)$. One $\mathrm{ml}\left(150 \mathrm{eggs} \cdot \mathrm{ml}^{-1}\right) \mathrm{of}$ egg suspension was taken in each well of a 24 well multiwell plate (Flow Laboratories). $500 \mu$ of different concentrations of oxfendazole were added to each experimental well while the control well received only the diluent $(0.1 \% \mathrm{NaCl})$. The plate was incubated at $27^{\circ} \mathrm{C}$ for $48 \mathrm{~h}$. After incubation, two drops of Lugol's iodine were added. At least 100 of the remaining eggs (dead and embryonated) and hatched larvae were counted.

Logarithmic concentration $\left(\mathrm{LC}_{50}\right.$ ) value was calculated for the eggs by log probit analysis (Finney 1971). Eggs having $\mathrm{LC}_{50}$ value in excess of $0.1 \mu \mathrm{g}$ oxfendazole per $\mathrm{ml}$ were indicative of anthelmintic resistance (Le Jambre 1976). 
For evaluation of flocks for the presence of anthelmintic resistance against oxfendazole, a scorecard was designed before the study to assess the role of some factors reported to contribute towards the development of anthelmintic resistance. Each factor contained three scores. For each parameter, it was assumed that the contributory role in the development of anthelmintic resistance increased in favor of anthelmintic resistance as score increased from one to three as follows:

Treatment frequency

$1=$ Yearly or more than a year, $2=$ After every six months, $3=$ After every three months or less

Dose rate

$1=$ Correct dose and to all the animals in a flock/herd, $2=$ Correct dose and to the animals suspected for worms in a flock/herd, 3 = Underdose

Rotation of anthelmintic compounds

$1=$ Strictly rotate, $2=$ Rotates after two years, $3=$ No rotation

Nature of anthelmintics

1 = Modern, 2 = Mixed modern and traditional, 3 = Traditional (ethnobotanicals)

\section{Results}

Percentage reduction in fecal egg counts and their confidence limits showed that resistance against oxfendazole was present at six farms $(n=6 / 18)$. Five farms $(n=5 / 18)$ were suspected for resistance and there was no evidence of resistance at seven farms (Table 1). Percentage reduction of fecal egg counts ranged from 80 to 100 percent (Table 1). The results of FECRT were also confirmed by egg hatch test (Table 2).

Table 2. LC50 values at flocks of goats with an evidence of development of resistance against Oxfendazole

\begin{tabular}{|c|c|}
\hline Flock No. & Oxfendazole $(\mathrm{LC} 50 \mu \mathrm{g} / \mathrm{mL})$ \\
\hline 1 & 0.14 \\
\hline 3 & 0.32 \\
\hline 4 & 0.61 \\
\hline 5 & 0.18 \\
\hline 16 & 0.96 \\
\hline
\end{tabular}

The distribution of nematode genera or species revealed that Haemonchus contortus was resistant at seven farms, Trichostrongylus colubriformis at six farms, $C$. curtice $i$ at six farms, Oesophagostomum spp. at four farms and no resistance was found in Teladorsagia circumcincta at all the three farms from which it was isolated. Anthelmintic resistance was suspected at six farms in $H$. contortus, at three farms in $T$. colubriformis, at four farms, in C. curticei, at two farms in Oesophagostomum spp. and at one farm against $T$. circumcincta (Table 3).

The data (Table 4) revealed that all the factors included in the study contributed to the development of resistance. Non-rotation of anthelmintic compounds was, however, found as the most significant contributory factor followed by treatment frequency, lower doses or selective treatments, and use of traditional medicines.

\section{Discussion}

As evident from the results, the parasites of great concern in this study were $H$. contortus, T. colubriformis, C. curticei, T. circumcincta and Oesophagostomum spp. as they cause the most severe clinical problems in this region (Malik et al. 1995). The frequent occurrence of trichostrongyluosis as a chronic rather than acute infection may allow the firm establishment of anthelmintic resistance without obvious clinical signs (J a ck s on et al. 1992). The present findings are not different from those reported from other countries as far as benzimidazole resistance is concerned (Uppal et al. 1992; Maingi et al. 1996; RequejoFernandez et al. 1997; Waruiru et al. 1998; Čorba et al. 1998; Čerňanská et al. 2006). 
Table 3. Percentage of larval cultures at different flocks of goats treated with oxfendazole

\begin{tabular}{|c|c|c|c|c|c|c|c|c|c|c|c|c|c|c|c|}
\hline \multirow{2}{*}{ Flock No. } & \multicolumn{3}{|c|}{$\begin{array}{l}\text { Haemonchus } \\
\text { contortus }\end{array}$} & \multicolumn{3}{|c|}{$\begin{array}{l}\text { Trichostrongylus } \\
\text { colubriformis }\end{array}$} & \multicolumn{3}{|c|}{$\begin{array}{l}\text { Cooperia } \\
\text { curticei }\end{array}$} & \multicolumn{3}{|c|}{$\begin{array}{c}\text { Teladorsagia } \\
\text { circumcinta }\end{array}$} & \multicolumn{3}{|c|}{$\begin{array}{l}\text { Oesophagostomum } \\
\text { spp. }\end{array}$} \\
\hline & $\%$ & $\mathrm{CL}$ & $\begin{array}{l}\mathrm{R} / \mathrm{S} \\
/ \mathrm{Sc}\end{array}$ & $\%$ & $\mathrm{CL}$ & $\begin{array}{l}\mathrm{R} / \mathrm{S} \\
/ \mathrm{Sc}\end{array}$ & $\%$ & CL & $\begin{array}{l}\mathrm{R} / \mathrm{S} \\
/ \mathrm{Sc} \\
\end{array}$ & $\%$ & $\mathrm{CL}$ & $\begin{array}{l}\mathrm{R} / \mathrm{S} \\
/ \mathrm{Sc}\end{array}$ & $\%$ & CL & $\begin{array}{l}\mathrm{R} / \mathrm{S} \\
/ \mathrm{Sc}\end{array}$ \\
\hline 1 & 85 & $55-95$ & $\mathrm{R}$ & 99 & $96-100$ & $\mathrm{Sc}$ & 93 & $77-98$ & $\mathrm{R}$ & - & - & - & - & - & - \\
\hline 2 & 100 & - & $\mathrm{Sc}$ & 100 & - & $\mathrm{Sc}$ & 100 & - & $\mathrm{Sc}$ & - & - & - & - & - & - \\
\hline 3 & 73 & $0-96$ & $\mathrm{R}$ & 74 & $0-96$ & $\mathrm{R}$ & 97 & $81-99$ & $\mathrm{~S}$ & 68 & $0-94$ & $\mathrm{R}$ & - & - & - \\
\hline 4 & 89 & $55-97$ & $\mathrm{R}$ & 93 & $73-98$ & $\mathrm{R}$ & 95 & $78-99$ & $S$ & 69 & $0-92$ & $\mathrm{R}$ & - & - & - \\
\hline 5 & 94 & $87-97$ & $\mathrm{R}$ & 87 & $72-94$ & $\mathrm{R}$ & 74 & $41-88$ & $\mathrm{R}$ & 98 & 96-99 & $\mathrm{Sc}$ & - & - & - \\
\hline 6 & 70 & $1-91$ & $\mathrm{R}$ & 87 & $57-96$ & $\mathrm{R}$ & 91 & $71-97$ & $\mathrm{R}$ & 87 & $57-96$ & $\mathrm{R}$ & 96 & $86-99$ & $S$ \\
\hline 7 & 99 & $92-100$ & $\mathrm{Sc}$ & 99 & $96-100$ & $\mathrm{Sc}$ & 98 & $85-100$ & $S$ & 100 & - & $\mathrm{Sc}$ & 100 & - & $\mathrm{Sc}$ \\
\hline 8 & 97 & $90-99$ & $\mathrm{Sc}$ & 97 & $90-99$ & $\mathrm{Sc}$ & - & - & - & 100 & - & $\mathrm{Sc}$ & - & - & - \\
\hline 9 & 95 & $68-99$ & $\mathrm{~S}$ & 96 & $76-99$ & $\mathrm{~S}$ & 91 & $38-99$ & $\mathrm{R}$ & 98 & $85-100$ & $\mathrm{~S}$ & - & - & - \\
\hline 10 & 97 & $87-99$ & $\mathrm{~S}$ & 93 & $66-98$ & $\mathrm{R}$ & - & - & - & 99 & $97-100$ & $\mathrm{Sc}$ & - & - & - \\
\hline 11 & 99 & $98-100$ & $\mathrm{~N}$ & 99 & 96-100 & $\mathrm{Sc}$ & 100 & - & $\mathrm{Sc}$ & 99 & $97-100$ & $\mathrm{Sc}$ & - & - & - \\
\hline 12 & 98 & $93-99$ & $\mathrm{~S}$ & 96 & $87-99$ & $\mathrm{~S}$ & 97 & $90-99$ & $\mathrm{Sc}$ & - & - & - & - & - & - \\
\hline 13 & 94 & $62-99$ & $\mathrm{R}$ & 98 & $86-100$ & $\mathrm{~S}$ & 97 & $81-100$ & $\mathrm{~S}$ & - & - & - & - & - & - \\
\hline 14 & 95 & $67-99$ & $S$ & 99 & $91-100$ & $\mathrm{Sc}$ & - & - & - & - & - & - & 99 & $91-100$ & $\mathrm{Sc}$ \\
\hline 15 & 97 & $87-99$ & $S$ & 99 & $95-100$ & $\mathrm{Sc}$ & 96 & 84-99 & $S$ & 100 & - & $\mathrm{Sc}$ & - & - & - \\
\hline 16 & 79 & $16-95$ & $\mathrm{R}$ & 91 & $63-98$ & $\mathrm{R}$ & 39 & $0-85$ & $\mathrm{R}$ & 54 & $0-89$ & $\mathrm{R}$ & - & - & - \\
\hline 17 & 97 & $93-99$ & $\mathrm{Sc}$ & 99 & $97-100$ & $\mathrm{Sc}$ & 68 & $16-88$ & $\mathrm{R}$ & 95 & $87-98$ & $\mathrm{~S}$ & - & - & - \\
\hline 18 & 98 & $84-100$ & $\mathrm{~S}$ & 99 & $91-100$ & $\mathrm{Sc}$ & 99 & $93-100$ & $\mathrm{Sc}$ & 99 & $90-100$ & $\mathrm{Sc}$ & - & - & - \\
\hline
\end{tabular}

$\%=$ Per cent reduction, $\mathrm{CL}=$ Confidence limits, $\mathrm{R}=$ Resistant, $\mathrm{S}=$ Suspected, $\mathrm{Sc}=$ Susceptible

Table 4. Composite scores (Mean \pm SE) based on contributory factors on different Beetal goat farms

\begin{tabular}{|c|c|c|c|c|}
\hline Status & $\begin{array}{c}\text { Treatment } \\
\text { frequency }\end{array}$ & Dose rate & $\begin{array}{c}\text { Rotation of } \\
\text { anthelmintic }\end{array}$ & $\begin{array}{c}\text { Nature of } \\
\text { anthelmintic }\end{array}$ \\
\hline Resistant $(\mathrm{n}=06)$ & $2.67 \pm 0.21 \mathrm{Aa}$ & $2.50 \pm 0.23 \mathrm{Aa}$ & $3.00 \pm 0 \mathrm{Ab}$ & $1.50 \pm 0.23 \mathrm{Ac}$ \\
\hline Suspected $(\mathrm{n}=05)$ & $2 \pm 0 \mathrm{Ba}$ & $1.6 \pm 0.25 \mathrm{Bb}$ & $2.8 \pm 0.20 \mathrm{Ac}$ & $1.4 \pm 0.25 \mathrm{Ab}$ \\
\hline Susceptible $(\mathrm{n}=07)$ & $1.29 \pm 0.19 \mathrm{Ca}$ & $1.00 \pm 0 \mathrm{Cb}$ & $1.86 \pm 0.14 \mathrm{Bc}$ & $1.0 \pm 0 \mathrm{Bb}$ \\
\hline
\end{tabular}

Different large alphabets in a column and small alphabets in a row indicate difference in mean scores for each parameter.

This study is, however, the first report of anthelmintic resistance in Beetal goats, which are among the most popular animals kept by the farmers in the area of study to meet their dayto-day needs.

Several factors affect the development of anthelmintic resistance in nematodes. The selection pressure exerted by the anthelmintic depends on the timing of use, underdosing and the drenching frequency (Sykes et al. 1992; Coles et al. 2006). Differences in bioavailability and efficacy for benzimidazole exist between sheep and goats. The repeated and exclusive use of benzimidazole products obviously led to the development of resistant nematode strains (Sykes et al. 1992); whereas, the impact of a continuous suboptimal dosage is more controversial (Borgsteede et al. 1996). Studies of the efficacy of benzimidazole in goats (Pomory 1996) suggest that it may be better to treat goats with drugs in the benzimidazole family at one-and-half or twice the recommended dosage. For instance, Bogan et al. (1987) found only a $42 \%$ bioavailability of oxfendazole in goats when compared with sheep after oral administration. In the present study, maximum contribution was found to be associated with the rotation of anthelmintics followed by 
treatment frequency, dose arte and nature of medication. Different contributory factors for AR have been reported by different workers (Jacks on 1993; V arady et al. 1994; Pal and Qayyum 1996; Shakoor et al. 1997; Van Wyk et al. 1997; Monteiro et al. 1998; Coles et al. 2006, Jabbar et al. 2006).

The reduction of the frequency of anthelmintic treatment together with an annual rotation in the type of anthelmintic used should also be a major goal for farmers to maintain the efficacy of available anthelmintics. Farmers should be educated in the importance of a correct use of anthelmintics in order to maintain their efficacy (Chandrawwathani et al. 1994). The reduction in the anthelmintic treatment will be feasible by keeping in mind the local epidemiology of trichostrongylosis and if some additional pasture management strategies are also developed (Coles and Roush 1992). Egg hatch assay was used to confirm the results of FECRT, which indicated development of resistance in gastrointestinal nematodes against OXF on all farms, in contrast to Martin et al. (1989) and Dorny et al. (1994).

The resistance management strategies may, therefore, be prioritized in view of the factors identified in the area of study. Designing a balanced approach may help the farmers in the management of resistance without compromising the production of animals.

\section{Rezistence stř̌evních nematod na oxfendazol u koz plemene Beetal na farmách v Pandžábu (Pákistán)}

Účelem této studie bylo testování kozích farem na rezistenci vůči anthelmintikům (AR) s oxfendazolem (OXF) a určení pomocných faktorů přispívajících k jejímu vzniku.

Za tímto účelem byly náhodně vybrány farmy chovající kozy plemene Beetal $(n=18)$ s přirozenou smíšenou infekcí gastrointestinálními nematody. Ke zjišsění přítomnosti AR byl in vivo použit test redukce počtu vajíček v trusu a in vitro test líhnutí vajíček. Výsledky byly využity k určení funkce možných pomocných faktorů pro rezistenci na oxfendazol. Pro test in vivo byla zvířata rozdělena do dvou skupin po deseti kusech. Jedna skupina byla ošetřena OXF, zatímco druhá sloužila jako kontrola. K identifikaci druhu nematod byla provedena kultivace fécés před a po ošetření, k potvrzení výsledku určení rodu testem FECRT byl použit test líhnutí vajíček (EHA).

Test redukce počtu vajíček v trusu (FECRT) odhalil vznik rezistence na šesti farmách a kultivací larev po ošetření byly jako dominantní druhy s rezistencí identifikovány Haemonchus contortus, Trichostrongylus colubriformis, Cooperia curticei, Teladorsagia circumcincta and Oesophagostomum spp. Mimoto EHA potvrdil výsledky FECRT. Z předpokládaných faktorů $A R$, mělo největší vliv střídání anthelmintik následované frekvencí ošetření, počtem dávek a způsobem podání. Výsledky této studie vývoje rezistence vůči anthelmintikům mohou být nápomocné při určování pomocných faktorů AR.

\section{Acknowledgements}

This research was funded by Pakistan Science Foundation, Islamabad, Pakistan.

\section{References}

ANCHETA PB, DUILON RA, VENTURINA VM, CERBITO WA, DOBSON RJ, LE JAMBRELF, VIOLLAR EC, GRAY GD 2004: Efficacy of benizmidazole anthelmintics in goats and sheep in the Philippines using a larval development assay. Vet Parasitol 102: 107-121

AZAD E, KHAN SA, KHANAND RM, KHAN MM 1997: Prevalence of gastrointestinal helminth parasites of sheep and goats in Quetta district of the province of Baluchistan, Pakistan. Pakistan J Zool 29: 259-262

BOGAN J, BENOIT E, DELATOUR P 1987: Pharmacokinetics of oxfendazole in goats: a comparison with sheep. J Vet Pharmacol Ther 10: 305-309

BORGSTEEDE FH PEKELDER JJ, DEREKSEN DP 1996: Anthelmintic resistant nematodes in goats in The Netherlands. Vet Parasitol 65: 83-87

ČERŇANSKÁ D, VÁRADY M, ČORBA J 2006: A survey on anthelmintic resistance in nematode parasites of sheep in the Slovak Republic. Vet Parasitol 135: 39-45 
CHANDRAWATHANI P, ADNANM, WALLER PJ 1999: Anthelmintic resistance in sheep and goat farms on Peninsular Malaysia. Vet Parasitol 82: 305-310

CHANDRAWATHANI P, PARAMESWARAN S, MOHD AN 1994: Antiparasitic drugs in selected sheep and goat farms in Western Malaysia. J Vet Malaysia 6: 61-64

COLES GC, ROUSH RT 1992: Slowing the spread of anthelmintic resistant nematode sheep and goat in U.K. Vet Rec 130: $505-510$

COLES GC, BAUER C, BORGSTEEDE FHM, GEERTS S, KLEI TR, TAYLOR MA WALLER PJ 1992: (W.A.A.V.P). Methods for the detection of anthelmintic resistance in nematodes of veterinary importance. Vet Parasitol 44: 35-44

COLES GC, JACKSON F, POMROY WE, PRICHARD RK, VON SAMSON-HIMMELSTJERNA G, SILVESTRE A, TAYLOR MA, VERCRUYSSE J 2006: The detection of anthelmintic resistance in nematodes of veterinary importance. Vet Parasitol 136: 167-185

ČORBA J, VARADY M, PRASLICKA J, TAMASOVICOVA O, KONIGOVA A 1998: Anthelmintic resistance in nematodes of domestic animals in Slovakia. Slovensky-Vet Casopis 23: 61-66

DORNY P, CLAEREBOUT E, VERCRUYSSE J, SANI R, JALILA A 1994: Anthelmintic resistance in goats in Peninsular Malaysia. Vet Parasitol 55: 327-342

FINNEY DI 1971: Probit Analysis. Cambridge University Press, Cambridge.

IQBAL Z, HAYAT CS, HAYAT B, KHAN MN 1986: Incidence of hydatidosis in Teddy goats slaughtered at Faisalabad abattoir. Pakistan Vet J 6: 70-72

IQBAL Z, LATEEF M, KHAN MN, MUHAMMAD G, JABBAR A 2005: Temporal density of trichostrongylid larvae on a communal pasture in a sub-tropical region of Pakistan. Pakistan Vet J 25: 87-91

JABBAR A, IQBAL Z, KERBOEUF D, MUHAMMAD G, KHAN MN, AFAQ M 2006: Anthelmintic Resistance: The State of Play Revisited. Life Sci 79: 2413-2431

JACKSON F, JACKSON E, LITTLE S, COOP RL, RUSSEL AJ 1992. Prevalence of anthelmintic-resistant nematodes in fibre-producing goats in Scotland. Vet Rec 131: 282-285

JACKSON F 1993: Anthelmintic resistance. The state of play. Brit Vet J 149: 123-37

KAPLAN RM 2004: Drug resistance in nematodes of veterinary importance: a status report. Trends Parasitol 20: 477-81

LATEEF M, IQBAL Z, JABBAR A, KHAN MN, AKHTAR MN 2005: Epidemiology of trichostrongylid nematode infections in sheep under traditional husbandry system in Pakistan. Int J Agri Biol 7: 596-600

Le JAMBRE 1976: Egg hatch as an in vitro assay of thiabendazole resistance in nematode. Vet Parasitol 2: 385-391

MAFF 1986. Mannual of Parasitological Laboratory Techniques. Her Majesty’s Stationary Office, London.

MAINGI N, BJORN H, THAMSBORG SM, BOGH O, NANSEN P 1996: A survey of anthelmintic resistance in nematode parasites of goats in Denmark. Vet Parasitol 66: 53-66

MALIK SZ, HAQ IU, JABEEN F, CHAUDHRY MA 1995: Incidence of endoparasites in ovine and caprine species in Punjab. Pakistan Vet J 15: 49-50

MARTIN PJ, ANDERSON N, JARETT RG 1989: Detecting benzimidazole resistance with faecal egg count reduction tests and in vitro assays. Aust Vet J 66: 236-240

MASCIE-TAYLOR CGN, KARIM E 2003: The burden of chronic disease. Science 302: 1921-1922

MCKENNA PB, BADGER SB, MCKINLEY RL, TAYLOR DE 1990: Simultaneous resistance to two or more broad spectrum anthelmintic by Gastro-intestinal nematode parasite of sheep and goat. New Zeal Vet J 38: 114-117

MILLER DK, CRAIG TM 1996: Use of anthelmintic combinations against multiple resistant Haemonchus contortus in Angora goats, Small Ruminant Res 19: 281-283

MONTEIRO AM, WANYANGU SW, KARIUKI DP, BAIN R, JACKSON F, MCKELLAR QA 1998: Pharmaceutical quality of anthelmintics sold in Kenya. Vet Rec 142: 396-398

MWAMACHI DM, AUDHO JO, THORPE W, BAKER RL 1995: Evidence for multiple anthelmintic resistance in sheep and goats reared under the same management in coastal Kenya. Vet Parasitol 60: 303-313

PAL RA, QAYYUM M 1996: A review of anthelmintic resistance in small ruminants: prevalence, recent understanding and future prospects for the nematodes control. Pakistan Vet J 16: 107-114

POMORY WE 1996: Anthelmintic resistance in goats. VI Int Conf on goats 6-11 May Beijing, China, pp.717-726.

RAZA AM, IQBAL Z, JABBAR A, YASEEN M 2007: Point prevalence of gastrointestinal helminthosis in ruminants in southern Punjab (Pakistan). J Helminthol (In Press).

REQUEJO-FEMANDEZ JA, MARTINEZ A, MEANA A, ROJO-VAZQUEZ FA, OSORO K, ORTEGA-MORA OM 1997: Anthelmintic resistance in nematode parasites from goats in Spain. Vet Parasitol 73: 83-88

SADDIQI HA, JABBAR A, IQBAL Z, BABAR W, SINDHU ZD, ABBAS RZ 2006: Comparative efficacy of five anthelmintics against trichostrongylid nematodes in sheep. Can J Anim Sci 86: 471-477

SHAKOOR O, TAYLOR RB, BEHRENS RH 1997: Assessment of the incidence of substandard drugs in developing countries. Trop Med Int Health 2: 839-845

SOULSBY EJL 1982: Helminths, Arthropods and Protozoa of Domesticated Animals. English Language Book Society, Baillière Tindall, London.

SYKES AR, MCFRLANE RG, FAMILTON AS 1992: Parasites, Immunity and anthelmintic resistance. In: Speedy AW (Ed.), Progress in sheep and goat research. CAB International, Wallingford Oxon, UK, pp. 179-191 
UPPAL RP, YADAV CL, GODARA P, RANA ZS 1992: Multiple anthelmintic resistance in a field strain of Haemonchus contortus in goats. Vet Res Commun 16: 195-198

VAN WYK JA, MALAN FS, VAN RENSBURG LJ, OBEREM PT, ALLAN MJ, 1997: Quality control in generic anthelmintics: is it adequate? Vet Parasitol 72: 157-165

VAN WYK JA, CABARET J, MICHAEL LM 2004: Morphological identification of nematode larvae of small ruminants and cattle simplified. Vet Parasitol 119: 277-306

VARADY M, PARASLICKA J, CORBA J 1994. Treatment of multiple resistant field strain of Ostertagia species in Cashmere and Angora goats. Int J Parasitol 24: 335-340

VAZQUEZ PV 2000: Agentes etiológicos y ciclo de vida de los nemátodos gastrointestinales. En. 1er . Curso Internacional "Nuevas perspectives en el diagnóstico y control de nematodos gastrointestinales en pequeños ruminates”. Universidad Autónoma de Yucatán. Facultad de Medicina Veterinaria y Zootecnia. Mérida, Yuc. 1-5

WALLER PJ 1986: Anthelmintic resistance in Australia. Parasitol Today 2: 16-18

WARUIRU RM, KOGI JK, WEDA EH, NGOTHO JW 1998: Multiple anthelmintic resistance on a goat farm in Kenya. Vet Parasitol 75: 191-197

ZAJAC AM, GIPSON TA 2000: Multiple anthelmintic resistance in a goat herd. Vet Parasitol 87:163-172 